\title{
$\mathrm{ZrN}$ 코팅된 치과 주조용 $\mathrm{Co}-\mathrm{Cr}$ 합금의 부식거동 \\ 이 상 훈, 나 정 숙, 장 재 영 \\ $\mathrm{e}^{-}$디온 치과기공소, 진주보건대학교 치기공과, 김천대학교 치기공학과
}

\section{Corrosion Behaviors of ZrN Coated on Dental Co-Cr Alloys}

\author{
Sang-Hun Lee, J ung-Sook Nah, J ae-Young J ang \\ e-Dion Dental Lab, Jinju Health College. Department of Dental Technology, Gimcheon University
}

\section{[Abstract]}

Purpose: The purpose of this study was to investigate to effect of the ZrN coated on corrosion resistance and physical property of dental $\mathrm{Co}-\mathrm{Cr}$ alloys using various instruments.

Methods: The specimens were used, respectively, for experiment, Arc lon plating was carried out for dental casting alloys using ZrN coated materials with nitrogen gas. ZrN coated surface of each specimen was observed with field emission scanning electron microscopy (FE-SEM), energy dispersive X-ray spectroscopy (EDS), vickers hardness tester, and electrochemical tester.

Results: The current density of ZrN coated specimen was smaller than that of non-coated specimen in $0.9 \%$ $\mathrm{N} \mathrm{aCl}$ solution. Pit nucleated at scratch of specimen. The pitting corrosion resistant $\left|E_{\max } E_{\text {rep }}\right|$ increased in order of $\mathrm{ZrN}$ coated $(110 \mathrm{mV})$, and non-coated wire $(100 \mathrm{mV})$.

Conclusion: The corrosion potential of the $\mathrm{ZrN}$ coated specimen was comparatively high. the surface of ZrN coated specimen was more smooth than that of other kinds of non-coated specimen. ZrN coated surface showed higher hardness than that of non-coated surface.

oKey words : corrosion resistance, electrochemical, ZrN coating

\begin{tabular}{c|c|c|c|c|c|c}
\hline \multirow{2}{*}{ 교신저자 } & 성 명 & 장 재 영 & 전 화 & 010-3851-5739 & E-mail & jeknock@yahoo.co.kr \\
\cline { 2 - 6 } & 주 소 & 경북 김천시 대학로 214번지 김천대학교 치기공과 & 확 정 일 & 2013.12 .23 \\
\hline \hline
\end{tabular}




\section{I. 서 론}

생체용 금속재료로서는 스텐레스강, $\mathrm{Co}-\mathrm{Cr}$ 합금, $\mathrm{Ti}$ 과 $\mathrm{Ti}$ 합금은 생체 적합성이 우수하여 대표적인 생체 재료로 사용되고 있다(Breme 등, 1995). 치과용 주조합금인 $\mathrm{Co}-\mathrm{Cr}$ 합금은 우수 한 내구성 및 내열성을 갖는다. 그러 나 고융점이기 때문에 용해를 비롯한 주조방법에 어려운 점이 있고 주조체에 결함이 발생하여 구강내에서 안정성 이 요구되고 있다.(Craig 등, 1979). 치과기공 과정에서 주조에 의하여 얻어진 주조체의 결함이 육안으로 확인되 지 않은 경우 결함이 있는 부위에서 파절되는 현상이 있 다고 한다(Earnshaw 등, 1956).

치과용 주조합금인 $\mathrm{Co}-\mathrm{Cr}$ 합금은 크롬산화막으로 부동 태막을 형성하여 부식저항성이 향상된다고 알려져 있다. 치과용 주조합금은 주조 시 주조결함으로 인하여 내식성 의 감소로 나타나며 결국은 주조체의 파절로 이어질 수 가 있다. 주조결함은 주조조직의 환경에 따라 구강환경에 서 쉽게 재료의 특성을 잃어버릴 수 있기 때문에 표면처 리가 필요 되어 진다. 또한 연한 골드색상의 피막이 코팅 되어 심미적으로 좋은 효과를 얻을 수 있다. 치과용 주조 합금인 $\mathrm{Co}-\mathrm{Cr}$ 합금은 산화피막에 의한 부동태형성으로 우수한 내식성을 갖고 있으나, 생체나 구강 내 환경에서 부식되면 조직이나 세포에 독성과 알레르기를 유발하여, 생체적합성의 효과가 감소되어질 수 있다. 최근 응용되고 있는 코팅방법은 $\mathrm{TiCl}_{4}, \mathrm{~N}_{2}$ 및 $\mathrm{H}_{2}$ 가스를 이용하는 CVD(chemical vapor deposition), ion-plating법을 포 함한 PVD(physical vapor deposition)법이 사용되고 있 다(Erturk 등, 1987). 과거에는 $\mathrm{ZrN}$ 과 $\mathrm{TiN}$ 코팅이 주로 CVD법에 의해 수행되었으나 반응가스에 의한 오염과 $600^{\circ} \mathrm{C}$ 이상의 고온처리에 따른 모체의 변형이 발생 되었 다(Santhanam 1993).

이를 피하기 위해 현제는 PVD법에 의해 처리되고 있으 며 그 중 ion-plating은 다른 PVD 방법에 비하여 코팅막 과 기지와의 접착력이 우수하다. 따라서 본 연구의 목적 은 현제 임상에서 사용되어지고 있는 대표적 치과 주조용 $\mathrm{Co}-\mathrm{Cr}$ 계 합금을 사용하여 합금조성과 주조방법을 다르 게 하여 주조한 후 Arc ion-plating법을 이용하여 생체 재료인 $\mathrm{ZrN}$ 코팅된 치과용 $\mathrm{Co}-\mathrm{Cr}$ 합금 표면의 전기화학
적 특성을 통하여 주조합금표면의 안정성을 실험하고자 하였다. 치과주조용 $\mathrm{Co}-\mathrm{Cr}$ 합금에 Arc ion-plating법을 이용하여 TiN을 코팅하여 연구한 것은 있으며 재료의 내 식성을 향상시키기 위하여 TiN코팅을 행하여 전해액에서 산화피막 $\left(\mathrm{TiO}_{2}\right)$ 의 형성을 촉진하여, 생체 적합성과, 재료 의 안정성을 증가시키고 $\mathrm{TiN}$ 박막이 결함부위를 막아 내 식성을 향상시키는 것으로 보고되어 있다(Ramalho 등, 1993). 그러나 생체재료인 $\mathrm{ZrN}$ 을 치과주조용 Co-Cr합 금에 코팅하여 내식성과 내마모성 및 생체안정성을 고찰 한 연구는 거의 없는 실정이다. 따라서 본 연구에서는 생 체용 금속으로 내마모 및 내식성이 우수한 $\mathrm{Co}-\mathrm{Cr}$ 합금에 우수한 내식성을 가진 $\mathrm{ZrN}$ 을 치과주조용 $\mathrm{Co}-\mathrm{Cr}$ 합금에 Arc ion-plating시킨 후 주조합금표면의 안정성과 부식 특성을 실험하였다.

\section{II. 연구 방법}

\section{1. 실험재료}

본 실험의 코팅과 부식시험에 사용된 $\mathrm{Co}-\mathrm{Cr}$ 합금은 $\mathrm{B}$ 사, T사에서 제조한 ingot을 사용하였다(T\&B Co, Grade. 4, USA).

실험에 사용된 시편은 $\mathrm{Co}-\mathrm{Cr}$ 합금인 Biosil(DeguDent Co,. GERMANY), Ticonium (Ticonium Co., USA)의 제품을 사용하였으며 합금의 화학적인 조성은 〈Table 1〉 과 같다.

실험에 사용된 시편은 $\mathrm{Co}-\mathrm{Cr}$ 계 합금으로 원심주조기 (Woosung Co. KOREA), 고주파유도주조기(Ticonium, Modular Co., USA)를 사용하여 원심주조법과 고구파유 도주조법으로 시편을 제작하여 방전가공 외주 처리방법 으로 일정한 모양과 뚜께로 절단한 후 미세조직관찰과, $\mathrm{ZrN}$ 코팅을 위하여 2000grit의 $\mathrm{SiC}$ 연마지까지 단계적 으로 습식 연마하고, 최종적으로 $0.3 \mu \mathrm{m}$ 알루미나 분말로 마무리 한 후 초음파 세척을 하였다.

준비된 시편은 $2 \mathrm{ml} \mathrm{HF}+3 \mathrm{ml} \mathrm{HCl}+5 \mathrm{ml} \mathrm{HNO}_{3}+190 \mathrm{~m} \ell$ $\mathrm{H}_{2} \mathrm{O}$ Keller's 용액으로 에칭한 후 FE-SEM과 EDX를 이 용하여 기지조직을 관찰하였다. $\mathrm{ZrN}$ 코팅은 타켓으로 $\mathrm{Zr}(99.99 \%, \mathrm{ASC} \mathrm{Co}, . \mathrm{KOREA})$ 의 고순도 질소를 사용하 
였다. ZrN 코팅은 Arc ion-plating(IDT, AMS0201, $\mathrm{KOREA}$ ) 장비를 사용하여 코팅하였으며 그 개략적인 구 조는 〈Fig. 1〉에 나타내었다.

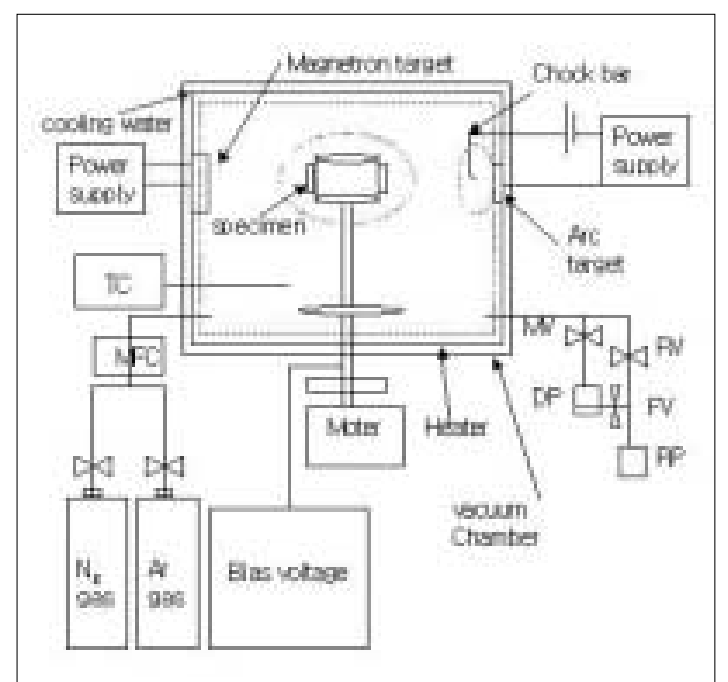

Fig. 1. Schematic diagram of Arc lon Plating system

\section{2. 시편제작}

실험에 사용된 시편은 $\mathrm{Co}-\mathrm{Cr}$ 계 합금으로 원심주조기 (Woosung Co. KOREA), 고주파유도주조기(Ticonium, Modular Co., USA)를 사용하여 원심주조법과 고구파유 도주조법으로 시편을 제작하여 방전가공 외주 처리방법 으로 일정한 모양과 뚜께로 절단한 후 미세조직관찰과, $\mathrm{ZrN}$ 코팅을 위하여 2000grit의 $\mathrm{SiC}$ 연마지까지 단계적 으로 습식 연마하고, 최종적으로 $0.3 \mu \mathrm{m}$ 알루미나 분말로 마무리 한 후 초음파 세척을 하였다.

준비된 시편은 $2 \mathrm{~m} \ell \mathrm{HF}+3 \mathrm{~m} \ell \mathrm{HCl}+5 \mathrm{~m} \ell \mathrm{HNO}_{3}+190 \mathrm{~m} \ell$ $\mathrm{H}_{2} \mathrm{O}$ Keller's 용액으로 에칭한 후 FE-SEM과 EDX를 이 용하여 기지조직을 관찰하였다. $\mathrm{ZrN}$ 코팅은 타켓으로 $\mathrm{Zr}(99.99 \%, \mathrm{ASC} \mathrm{Co}, . \mathrm{KOREA})$ 의 고순도 질소를 사용하 였다. $\mathrm{ZrN}$ 코팅은 Arc ion-plating(IDT, AMS0201, $\mathrm{KOREA}$ ) 장비를 사용하여 코팅하였으며 그 개략적인 구 조는 〈Table 2〉에 나타내었다.

Table 1. Chemical composition of $\mathrm{Co}-\mathrm{Cr}$ alloys

\begin{tabular}{|c|c|c|c|c|c|c|c|c|}
\hline sample & composition(wt\%) & C॰ & $\mathrm{Cr}$ & M• & Si & $\mathrm{Mn}$ & C & $\mathrm{N}$ \\
\hline & \# alloy B & 64.8 & 28.5 & 5.3 & 0.5 & 0.5 & 0.4 & \\
\hline & \# alloy T & 62.4 & 28.5 & 6 & & & & 1 \\
\hline
\end{tabular}

Table 2. Materials of specimens

\begin{tabular}{ccl}
\hline Type & Name & \multicolumn{1}{c}{ Treatment } \\
\hline \multirow{3}{*}{ \# alloy B } & BC & centrifugal casting \\
& BCC & ZrN coated centrifugal casting \\
& BHC & high frequency induction casting \\
& BHCC & ZrN coated high frequency induction casting \\
\hline \# alloy $T$ & TC & centrifugal casting \\
& TCC & ZrN coated centrifugal casting \\
& THC & high frequency induction casting \\
& THCC & ZrN coated high frequency induction casting \\
\hline
\end{tabular}

Arc ion-plating은 코팅막을 만들기 위해서 초고순도 $\mathrm{N}$ 와 $\mathrm{Ar}$ 이 사용되었다. 초기진공은 로터리펌프를 사용하 여 $10^{-2}$ torr까지 진공도를 유지한 후, 오일확산 펌프를 사 용하여 $10^{-5}$ torr까지 진공도를 떨어뜨렸다. 진공도확인은
페닝 게이지를 사용하여 확인하였으며 기판의 온도는 $150 \sim 250^{\circ} \mathrm{C}$ 로 하였다. 시험편을 장착한 후에 진공챔버를 $3.0 \times 10^{-3}$ torr까지 배기시키고 mass flow controller를 이용하여 Ar gas를 20 30 sccm로 공급하였다. 이후 
$60 \mathrm{~A}$ 의 power로 $\mathrm{Ar}$ 플라즈마를 발생시킨 후 시료대에 $\mathrm{DC}$ 를 인가하여 약 20 분 동안 산화층을 비롯한 시험편 표 면의 오염 물질을 제거한 후, 진공챔버를 다시 $1.0 \times 10^{-5}$ torr로 배기시켰다. Arc ion-plating을 위하여 $\mathrm{ZrN}$ 코팅 의 경우 N2 gas를 20 30 sccm로 공급하였으며 코팅시 간을 $20 \mathrm{~min}$ 으로 하여 코팅층의 뚜께가 $3.0 \sim 3.5 \mu \mathrm{m}$ 가 되 도록 하였다. 시편의 회전속도는 $0,5 \mathrm{RPM}$ 으로 하여 시편 의 모든 부위가 균일하게 이루어지도록 하였으며 접착도 를 증가시키기 위하여 온도는 $150 \sim 250^{\circ} \mathrm{C}$ 로 하였다. 코 팅의 조건은 〈Table 3〉에 나타내고 있다. 전기화학적 방 법을 이용한 부식시험은 potentiostat(model:263A, EG $\&$ G Co., USA)을 사용하여 동전위 법으로 실시하였다. 전해액 $600 \mathrm{~m} \ell$ 를 넣고 각각의 시편을 정전위 장치에 연결
한 후 포화칼로멜전극(saturated calomel electrode, $\mathrm{SCE}$ )을 표준전극으로 하였으며 작업전극은 준비된 시편 으로 하였다. 시편과 표준전극(reference electrode)간의 거리를 약 $1 \mathrm{~mm}$ 로 조절하였으며, 보조전극(counter electrode)으로 고밀도 탄소전극을 사용하였다. 양극분극 곡선(anodic polarization electrode)을 얻기 위해 36.5 $\pm 1^{\circ} \mathrm{C}$ 의 $0.9 \% \mathrm{NaCl}$ 전해액( $\mathrm{pH}$ 가 5.34)에서 동전위방법 을 이용하여 $100 \mathrm{mV} / \mathrm{min}$ 의 주사속도로 $-1500 \mathrm{mV}$ 에서 $+1500 \mathrm{mV}$ 까지 전위를 걸어 1 차 전기화학적 부식시험을 하 였으며 실험시마다 시편과 전해액을 교환하였다. $\mathrm{X}$ 축은 전류밀도의 로그값을 Y축은 전위로 하여 곡선을 얻었다. 부식 후 합금의 거동은 $\mathrm{FE}-\mathrm{SEM}$ 을 통하여 조사하였다.

Table 3. Deposition condition of ZrN film on the alloys

\begin{tabular}{ll}
\multicolumn{1}{c}{ Coating condition } & \multicolumn{1}{c}{ ZrN film } \\
\hline Target & ZrN $(99.9 \%)$ \\
Base pressure & $3 \times 10^{-2}$ torr \\
Working pressure & $1 \times 10^{-5}$ torr \\
Gas & $\mathrm{N} 2(25 \mathrm{sccm})+\mathrm{Ar}(25 \mathrm{sccm})$ \\
Operation Temperature & 200 \\
\hline lon-plating & $20 \mathrm{~min}$ \\
Power & $60 \mathrm{~A}$ \\
\hline
\end{tabular}

\section{3. 실험방법}

\section{1) 코팅표면조사 및 경도조사}

$\mathrm{ZrN}$ 으로 코팅된 치과용 $\mathrm{Co}-\mathrm{Cr}$ 합금의 코팅표면을 관찰 하기위하여 주사전자현미경(JSM-6380-LV, Japan)으 로 관찰하였고 코팅표면 성분을 조사하기 위하여 $\mathrm{EDS}$ (Dispersive X-ray spectrometer)를 이용하여 성분 분 석하였다. $\mathrm{ZrN}$ 코팅된 시편에 vickers 경도계를 이용하 여 코팅경도를 측정하였다.

\section{2) 부식거동조사}

코팅하지 않은 시편과 $\mathrm{ZrN}$ 을 코팅한 경우의 시편의 부 식거동을 조사하고자 하였다. 또한 동일한 시편에서 주조 방법을 달리하여 원심주조법으로 제작한 시편과 고주파 주조법으로 제작한 시편을 각 표면에 코팅하여 부식시험
은 potentiostat(model:263A, EG \& G Co., USA)을 사 용하여 동전위법으로 실시하였다.

\section{III. 결 과}

$\mathrm{ZrN}$ 이 코팅된 경우와 코팅되지 않은 시편과 원심주조 법과 고주파주조법으로 주조된 경우의 코팅표면과 부식 특성을 관찰실험 하였다.

\section{1. 주조합금의 주조방법에 따른 조직변화}

주조합금조직은 \# alloy B, \# alloy T $\mathrm{Co}-\mathrm{Cr}$ 합금에서 수지상구조(dendritic structure)를 보였으며 $\alpha \sim \mathrm{Co}, \varepsilon \sim$ $\mathrm{Co}$ 상이 나타났다. 원심주조법에서는 수지상구조(dendritic 
structure)가 크게 관찰되었다(Fig. 4(a)). 고주파유도 주 조법에서는 수지상조직이(dendritic structure)가 작아져 보임을 알 수 있다(Fig. 4(b)). 특히 원심 주조법의 경우에 는 기지(matrix)에 많은 pit이 보여 주조결함이 많음을 보 여주고 있다(Fig. 2).

\section{2. 코팅표면조사 및 경도조사}

$\mathrm{ZrN}$ 을 코팅된 치과용 $\mathrm{Co}-\mathrm{Cr}$ 합금의 코팅표면을 $\mathrm{FE}-$ $\mathrm{SEM}$ 으로 조사한 결과를 나타내었다. $\mathrm{ZrN}$ 코팅된 시편에 vickers 경도계를 이용하여 코팅경도를 측정한 결과 표면 에 나타난 압흔 자국으로부터 구한 경도값이 $\mathrm{ZrN}$ 을 코팅 한 경우는 250 410정도로 동일한 조건에서도 금속의 종 류와, 주조방법에 따라 약간의 차이를 보였다. 코팅하지 않은 경우는 경도가 대체로 낮게 나타났다(Fig. 9).

코팅하지 않은 시편보다는 $\mathrm{ZrN}$ 을 코팅한 경우의 경도 가 높게 나타났다. 표면에 나타난 압흔 자국의 크기가 코 팅하지 경우 크게 나타나고, $\mathrm{ZrN}$ 이 코팅된 경우는 작게 나타나 표면경도가 높음을 알 수 있는데 이는 $\mathrm{ZrN}$ 을 코팅 한 경우의 경도가 증가되어 안정한 코팅 막을 보임을 알 수 있다. 일반적으로 강에 코팅을 할 경우 $\mathrm{ZrN}$ 은 $2500 \mathrm{~kg}$ $/ \mathrm{mm}$ 을 나타낸다고 보고하고 있어 대체적으로 $\mathrm{ZrN}$ 피막이 안정하고 표면의 특성이 좋음을 알 수 있다. 따라서 표면 에 높은 강도와, 표면의 균질함을 얻을 수 있는 조건이 $\mathrm{ZrN}$ 을 코팅한 경우임을 알 수 있다.

\section{ZNN 코팅된 시편의 ZNN 부식거둥조사}

원심주조법과 고주파유도용해주조법으로 제조한 시편 에서 원심주조법인 경우 주조조직의 결함으로 인하여 동 전위분극곡선에서 부식전위와 공식전위가 낮아지고 전류 밀도가 증가하였다. 반면에 고주파유도용해주조법으로 제조한 시편의 경우에는 부식전위가 높아지고 전류밀도 가 전반적으로 감소하였다. 특히 합금성분에 따른 결과는 \# alloy B에서보다 \# alloy T에서 높은 공식전위값을 보 였다(Fig. 6). ZrN을 코팅한 시편의 표면에서 코팅하지 않은 경우와, 원심주조와 고주파유도용해주조에서 공식 전위가 증가함을 보였으며 이는 합금성분의 차이로 인한 코팅표면층의 뚜께로 인해 코팅효과가 크게 나타났다. $\mathrm{ZrN}$ 코팅된 시편의 단면을 $\mathrm{FE}-\mathrm{SEM}$ 으로 코팅된 시편의
표면이 작은 알갱이로 구성된 $\mathrm{ZrN}$ 물질이 존재함을 알 수 있으며 이것을 micro droplet이라 한다(Fig. 2). micro droplet의 입자가 크게 형성 될수록 표면처리의 결함이 쉽 게 일어날 수가 있다고 알려져 있다. 또한 시편의 단면에서 코팅표면에 주상정결정이 성장함을 보였으며 $\mathrm{EDS}$ 를 이용 하여 $\mathrm{Si}$ 기판 표면에 코팅하여 코팅 막의 성분을 분석한 결 과, $\mathrm{ZrN}$ 의 주 피크인 $\mathrm{Zr}$ 성분이 주로 검출되고 있음을 알 수 있다(Fig. 5). 또한 $\mathrm{ZrN}$ 코팅된 시편의 경우 부식전위와 전류밀도가 감소되어졌다(Fig. 6). 코팅된 시편의 경우, 코 팅되지 않은 시편에 비하여 왼쪽에 위치하여 전류밀도 값 이 감소하는 경향을 보였다(Fig. 7). ZrN 코팅한 경우에는 곡선이 왼쪽에 위치하여 내식성이 증가하였으며 구강 내 최대전위인 $250 \mathrm{mV}$ 대에서 전류밀도 값은 $\mathrm{ZrN}$ 코팅된 $\mathrm{THFC}$ 에서 $8.0 \times 10^{-5} \mathrm{~A} / \mathrm{cm}^{2}$, 코팅하지 않은 경우는 $\mathrm{BC}$ 에서 $7.0 \times 10^{-5} \mathrm{~A} / \mathrm{cm}^{2}$ 를 나타내어 $\mathrm{ZrN}$ 코팅한 경우에는 전류밀도 가 가장 낮게 나타났다. 공식전위는 $\mathrm{THFC}$ 에서 $\mathrm{ZrN}$ 코팅 한 경우는 $110 \mathrm{mV}$ 를, 코팅하지 않은 경우는 $100 \mathrm{mV}$ 로 낮게 나타나 $\mathrm{ZrN}$ 을 코팅한 경우가 높게 나타났다(Fig. 8). 시편 에 $\mathrm{ZrN}$ 을 코팅한 경우는 코팅하지 않은 경우에 비하여 왼 쪽에 위치하였으며, 공식 저항성은 $\mathrm{ZrN}$ 을 코팅한 경우가 높게 나타났다. $\mathrm{ZrN}$ 의 코팅된 부식시험결과 코팅된 시편 의 경우 코팅되지 않은 시편에 비하여 전류밀도가 전체적 으로 감소하여 왼쪽에 위치하여 전류밀도 값이 감소하는 경향을 보였다. 각 시편의 부식특성차이는 코팅된 시편이 내식성이 우수하게 나타났다(Fig. 8).

부식시험 후 부식표면을 관찰한 결과를 〈Table 4〉에 나 타내었다. (Fig. 3)은 코팅한 시편의 부식사진으로 코팅되 지 않은 (a)는 큰 pit를 보였다. 그러나 $\mathrm{ZrN}$ 을 코팅한 (b)에 서는 (a)와 같이 큰 pit는 발견되지 않았지만 미세한 pit가 발견되었다. 〈Fig. 3〉은 시편의 부식양상이다. 코팅하지 않은 경우는 표면에 많은 pit를 보이며 코팅하면 그 수와 크기가 작게 나타났다. 〈Fig. 3〉, 〈Fig. 4〉에 나타난 사진 과 같이 $\mathrm{FE}-\mathrm{SEM}$ 을 이용하여 더 자세히 1000 배로 관찰 하면 코팅하지 않은 경우는 많은 pit가 발견된 반면, 코팅 을 행하면 〈Fig. 3(b)〉에서 알 수 있듯이 pit의 수와 크기 가 크게 감소함을 보였다. 부식 후 표면에 형성된 부식 생 성물을 분산 $\mathrm{X}-$ 선 분광기를 통하여 검사한 결과 $〈 F i g$. $3\rangle$, 〈Fig. 4〉에 나타난 바와 같이 $\mathrm{ZrN}$ 을 코팅한 경우에는 
$\mathrm{Zr}, \mathrm{N}, \mathrm{Cr}, \mathrm{Fe}, \mathrm{Ma}, \mathrm{Cl}$ 등이 검출되었다. 이는 $\mathrm{ZrN}$ 의 경 우, $\mathrm{TiN}(\mathrm{ZrN})+\mathrm{O}_{2} \longrightarrow \mathrm{TiO}\left(\mathrm{ZrO}_{2}\right)+1 / 2 \mathrm{~N}_{2}$ 과 같은 반응이 촉 진되고, 따라서 $\mathrm{TiO}_{2}, \mathrm{TiO}_{2} \mathrm{~N}$, 및 $\mathrm{TiO}_{2} \cdot \mathrm{H}_{2} \mathrm{O}, \mathrm{ZrO}_{2}$ 가 표 면에 형성됨으로써 $\mathrm{Cl}^{-}$에 대한 저항을 하여 억제하기 때 문으로 생각된다. 이와 같이 코팅하지 않은 경우는 많은 pit가 표면에서 발견되고 있으며, $\mathrm{ZrN}$ 코팅을 행하면 pit 의 수가 크게 감소하여 내공식성이 크게 증가함을 알 수 있다. 부식 후 표면에서 $\mathrm{ZrN}$ 이 코팅된 경우는 주로 $\mathrm{Zr}$,
$\mathrm{N}, \mathrm{Fe}, \mathrm{Cr}, \mathrm{Ma}, \mathrm{Cl}$ 등이 검출되었는데 이는 $\mathrm{TiN}(\mathrm{ZrN})+$ $\mathrm{O}_{2} \rightarrow \mathrm{TiO}_{2}\left(\mathrm{ZrO}_{2}\right)+1 / 2 \mathrm{nN}_{2}$ 과 같은 반응(D. M. Brunette, P.Tengvall, M. Txtor,Thomsen, Sringer, (2001). 이 촉진되고 따라서 $\mathrm{ZrO}_{2}$ 가 표면에 형성됨으로써 $(\mathrm{H} . \mathrm{C}$. Choe, Technol., (1989). Cl-에 대한 저항을 하여 공식을 억제하기 때문이다. 이러한 결과를 토대로 스테인레스강 의 표면에 $\mathrm{ZrN}$ 을 코팅하여 내식성을 증가 시킬 수 있을 것으로 생각된다.

Table 4. Corrosion current density(Epit), repassivation potential(Erep) of $\mathrm{Co}-\mathrm{Cr}$ alloy after electrochemical test in $0.9 \%$ $\mathrm{NaCl}$ solution at $36.5 \pm 1^{\circ} \mathrm{C}$

\begin{tabular}{|c|c|c|c|c|c|c|c|c|}
\hline \multirow{2}{*}{$\begin{array}{l}\text { Non } \\
(\mathrm{ZrN})\end{array}$} & \multicolumn{4}{|c|}{ Centrifugal casting } & \multicolumn{4}{|c|}{ high frequency casting } \\
\hline & $\mathrm{BC}$ & TC & $\mathrm{BCC}$ & TCC & $\mathrm{BHF}$ & THF & BHFC & THFC \\
\hline $1250 \mathrm{mv}\left(\mathrm{A} / \mathrm{cm}^{2}\right)$ & $7.0 \times 10^{-5}$ & $6.0 \times 10^{-5}$ & $7.0 \times 20^{-3}$ & $6.0 \times 10^{-5}$ & $2.0 \times 10^{-5}$ & $6.0 \times 10^{-5}$ & $2.0 \times 10^{-6}$ & $8.0 \times 10^{-5}$ \\
\hline Epit (nV) & -980 & 550 & -280 & 110 & -600 & 120 & -500 & 500 \\
\hline Erep (nV) & -800 & 300 & -350 & 10 & -750 & -220 & -550 & 410 \\
\hline | Emax- Erep| & 100 & 250 & 70 & 100 & 150 & 100 & 50 & 10 \\
\hline
\end{tabular}

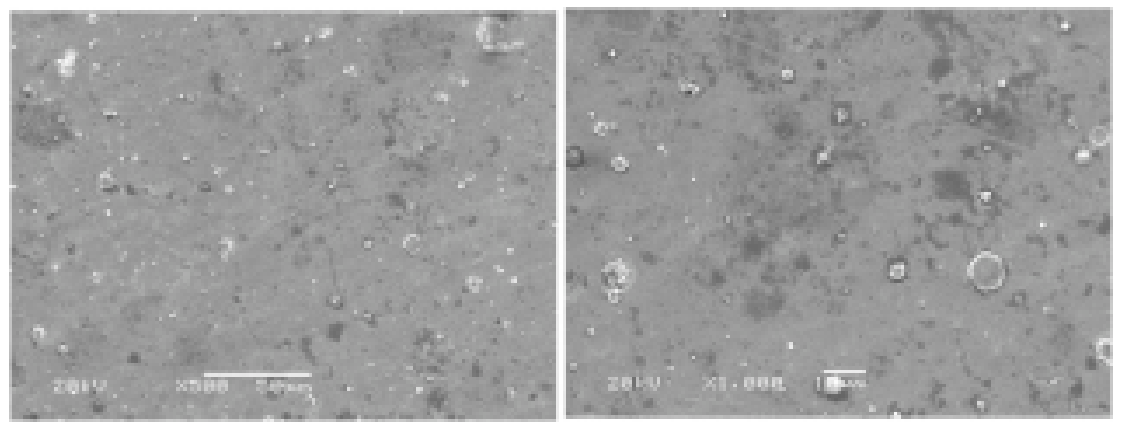

Fig. 2. FE-SEM macro droplet showing ZrN coated of $\mathrm{Co}-\mathrm{Cr}$ alloys

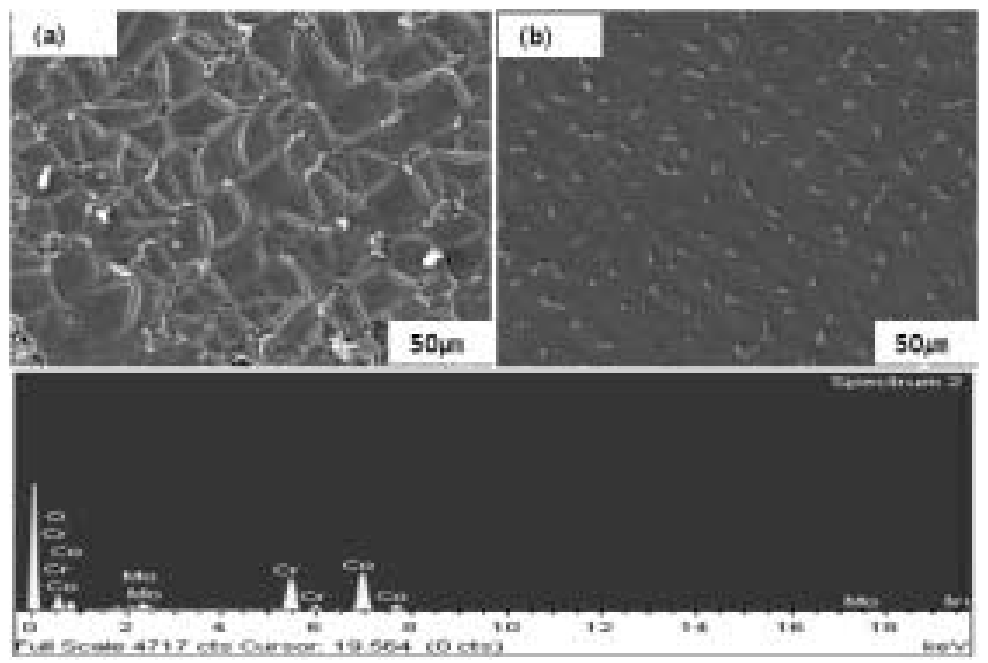

Fig. 3. FE-SEM micrographs showing casting structure B-alloy. (a)centrifugal casting (b) high frequency induction casting 


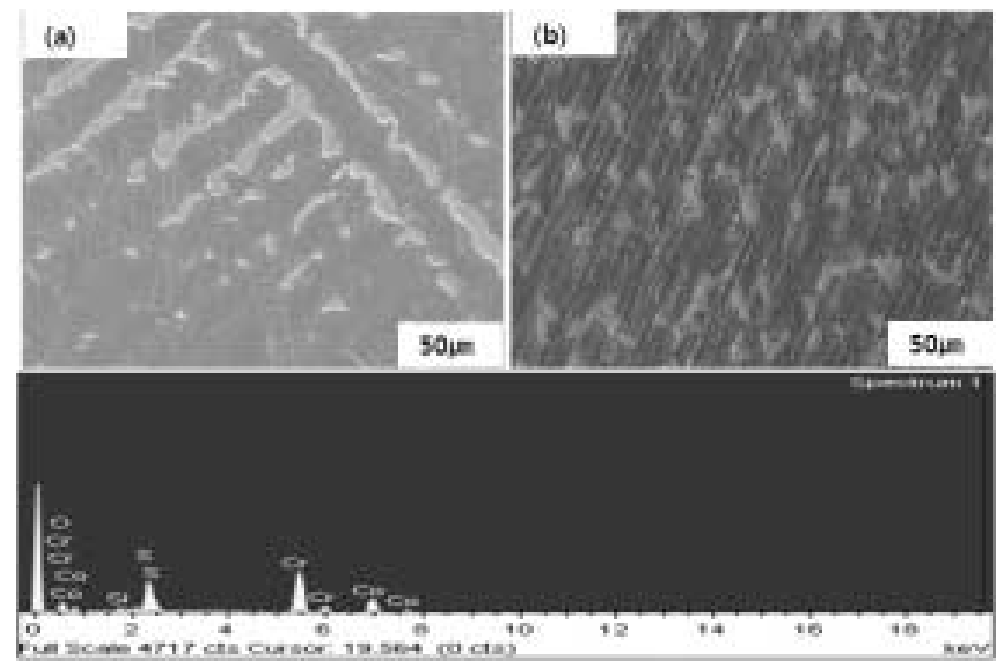

Fig. 4. FE-SEM micrographs showing casting structure T-alloy. (a) centrifugal casting (b) high frequency induction casting

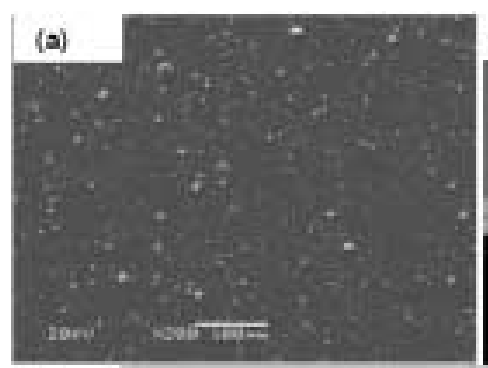

(b)

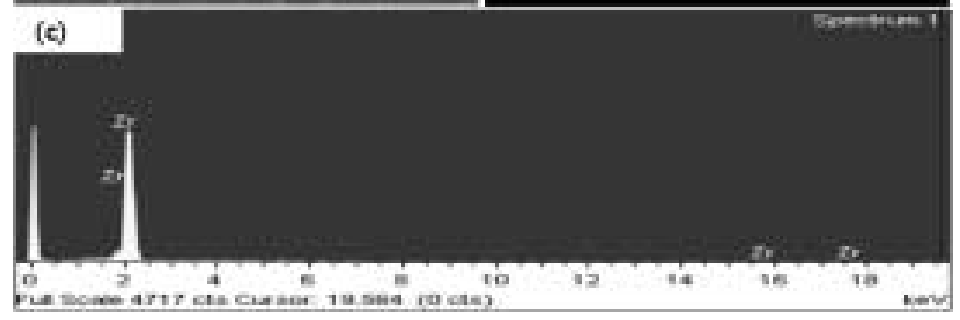

Fig. 5. FE-SEM micrographs and EDX showing ZrN coated surface (a), layer (b) and EDS peak (c)

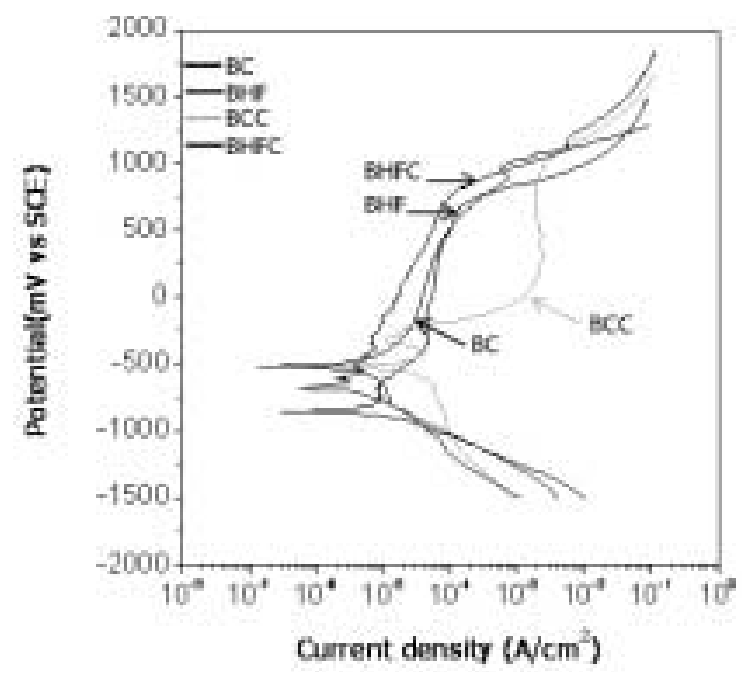

Fig. 6. Anodic polarization curves of $\mathrm{Co}-\mathrm{Cr}$ alloy after potentiodynamic test in $0.9 \%$ NACL solution at $36.5 \pm{ }^{\circ} \mathrm{C}$ 


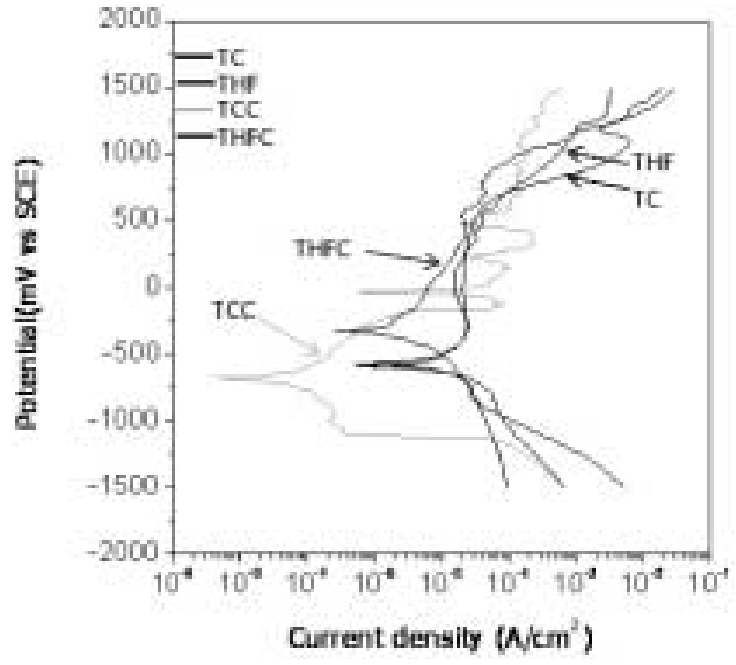

Fig. 7. Anodic polarization curves of $\mathrm{Co}-\mathrm{Cr}$ after potentiodynamic test in $0.9 \%$ NACL solution at $36.5 \pm^{\circ} \mathrm{C}$

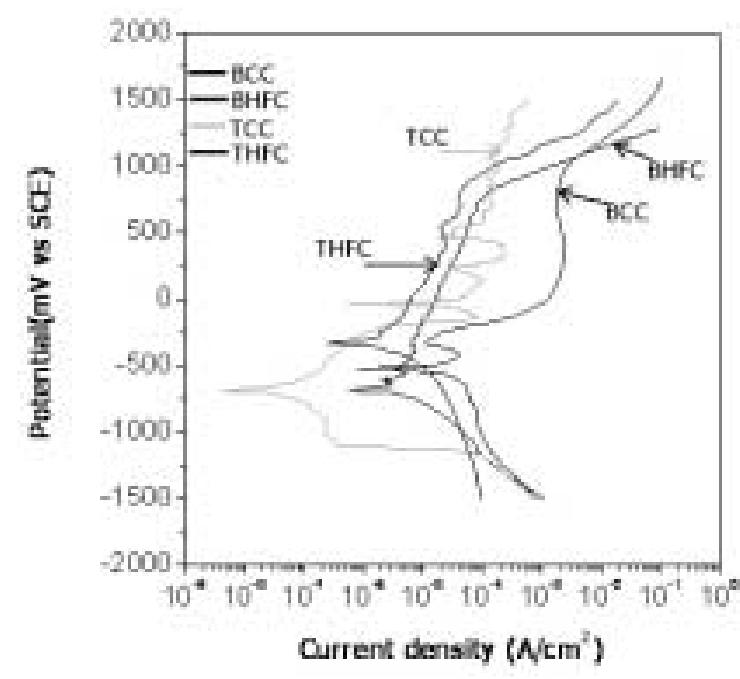

Fig. 8. Anodic polarization curves of \# alloy1 and after potentiodynamic test in $0.9 \%$ NACL solution at $36.5 \pm{ }^{\circ} \mathrm{C}$

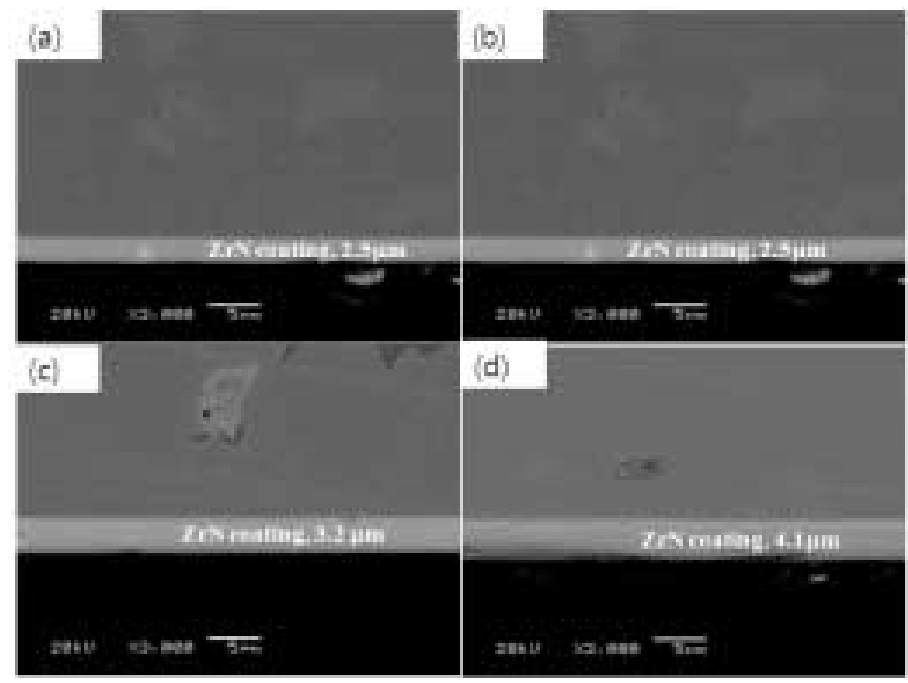

\begin{tabular}{lcccc}
\hline & BCC & BHFC & TCC & THFC \\
\hline$H \vee(\mathrm{m})$ & 2.5 & 3.4 & 3.2 & 4.1 \\
\hline Zrn coated $(\mathrm{m})$ & 2.5 & 2.5 & 3.2 & 4.1 \\
\hline
\end{tabular}

Fig. 9. Arc lon plating coated and Hv of non-coated and coated Co-Cr alloys BCC (a) BHFC (b) TCC (c) THFC (d)

\section{IV. 고 찰}

치과용 주조합금은 치과기공 과정 중에서 주조방법에 따른 주조체의 결함으로 인해 파절 및 치주질환으로 이어 질 수 있다. 본 연구에서는 내마모 및 내식성이 우수하고 연한 골드색의 색상을 나타내며, 현재까지의 연구자들에 따르면 코팅 층의 높은 경도와 인성 및 모재-박막층간의
우수한 접착력을 얻기 위하여 모재의 온도가 중요하다고 하여 Arc ion-plating 방법을 이용 원모재의 온도를 조 절하여 원심주조법과 고주파유도주조법으로 코팅을 하였 고 양호한 코팅표면을 얻을 수 있었다. 심미성을 겸비한 생체용 합금인 $\mathrm{ZrN}$ 코팅된 치과보철용 $\mathrm{Co}-\mathrm{Cr}$ 합금 주조 체의 부식특성을 조사하였다. 치과보철물은 주조과정 과 정중 불순물의 혼입 등 여러 요소들이 수축공, 미세균열, 
기공등의 결함과 불순물의 혼입등이 나타난다(Civjan 등, 1972).

주조조직을 $\mathrm{FE}-\mathrm{SEM}$ 으로 관찰해보면 원심주조법에서 주조결함이 더 많이 발견되었다. 합금의 종류에 따라서는 \# alloy T에서 주조결함이 적게 나타났다. 또한 고주파유 도용해로 주조된 시편에서보다 원심주조법에서 수지상구 조가 크게 나타남을 알 수 있었다.

Arc ion-plating 방법으로 코팅된 $\mathrm{ZrN}$ 피막에서 온도 가 높을수록 코팅이 우수하였다. 이는 주상정의 조직이 특정방향으로의 결정이 성장하는데 이러한 성장은 코팅 온도, 코팅속도, 모재에 따라 좌우되며 치밀한 성장은 표 면결함의 감소와 내식성과 내마모성을 증가시킬 수 있다 (Brunette 등, 2001)와 일치한다. 이는 \# alloy T에서 $\mathrm{ZrN}$ 코팅된 시편에서 알 수 있었다. 동일한 조건의 실험 조건 속에서 $\mathrm{Co}-\mathrm{Cr}$ 합금의 조성에 따라 코팅 층의 두께가 달라졌으며 \# alloy B에서보다 \# alloy T가 상대적으로 코팅이 우수하게 나타났으며 코팅 층의 두께가 표면부식 특성에 영향을 미치는 것을 알 수 있었다(Fig. 8). 합금에 따라서는 \# alloy B보다 \# alloy T에서 우수한 코팅 두께 가 형성 되어졌으며 우수한 내공식 특성이 나타났다. 또 한 원심주조법을 이용한 시편에서보다 고주파 주조법으 로 제작된 시편에서 $\mathrm{ZrN}$ 코팅이 잘 수행되어졌다(Fig. 9). 이는 원심주조법의 미세조직변화가 부식특성에 영향을 미치는 것으로 사료된다. $\mathrm{FE}-\mathrm{SEM}$ 의 표면관찰에서 수지 상구조의 형태가 원심주조에서 크게 형성되어짐을 알 수 있었다(Fig. 4). 또한 시편의 표면에서 생기는 주조결함이 코팅층 형성에 영향을 미치는 것도 부식실험을 통하여 알 수 있었다(Fig. 6). 동일한 시험조건 속에서 수행되어진 $\mathrm{ZrN}$ 코팅 실험에서 시편의 코팅층의 뚜께가 달라졌으며, 원심주조법과 고주파 유도 용해 주조법에서도 코팅층의 두께가 달라졌음을 알 수 있었다(Fig. 9). 또한 코팅층의 두께에 따른 시편 표면의 색상변화가 미세하게 나타났으 며 이것이 부식특성에 영향을 미치는 것도 알 수 있었다. 공식의 저항성을 나타내는 $\left|\mathrm{Emax}_{\max }-\mathrm{E}_{\mathrm{rep}}\right|$ 값이 주조방법 에 따라 $980 \mathrm{mV}$ 에서 $600 \mathrm{mV}$ 로 감소하여 내공식성이 증가 하여 증가하였으며, $\mathrm{ZrN}$ 코팅이 된 이후에는 $800 \mathrm{mV}$ 에서 $350 \mathrm{mV}$ 로 감소하여 내식성이 크게 증가하였다(Table 3). 본 실험에서는 생체용 금속인 $\mathrm{ZrN}$ 을 Arc ion-plating
방법을 이용하여 자연치와 유사한 색상재현을 통한 심미 성향상 및 치과보철물의 품질향상에 기여하고자 실험하 였다.

이번 실험은 제한된 $\mathrm{Co}-\mathrm{Cr}$ 합금에 한정되어 코팅 실험 되어졌고 더 많은 합금조성의 시편을 대상으로 실험하지 못하였다. 또한 치과용 주조합금인 $\mathrm{Ni}-\mathrm{Cr}$ 합금에 대한 코 팅의 표면 부식특성을 실험하지 못해 이에 대한 폭넓은 연구도 필요하다. 아울러 기능적, 경제적 측면 등 실용화 에 필요한 임계 코팅층에 대한 추가연구가 필요할 것으로 사료된다.

\section{V. 결 론}

치과 주조용으로 사용되는 대표적인 금곡인 치과주조용 $\mathrm{Co}-\mathrm{Cr}$ 합금을 원심주조법, 고주파유도주조법의 2 가지 주 조법을 이용하여 시편을 제조한 후, 시편표면에 Arc Ion plating을 이용하여 $\mathrm{ZrN}$ 을 코팅하여 $0.9 \% \mathrm{NaCl}$ 용액에 서 전기화학적 안정성을 조사하여 아래와 같은 결론을 얻 었다.

1. $62.4 \mathrm{Co}-28.5 \mathrm{Cr}-6 \mathrm{Mo}$ 합금(\#alloy $\mathrm{T}$ )과 $64.8 \mathrm{Co}-$ $28.5 \mathrm{Cr}-5.3 \mathrm{Mo}$ 합금(\#alloy B)에서 $\mathrm{ZrN}$ 코팅된 합금에 서는 $\alpha-\mathrm{Co}$ 와 $\varepsilon-\mathrm{Co}$ 상이 나타났으며 $\mathrm{ZrN}$ 을 코팅하면 균 일한 코팅표면을 보였다.

2. 경도를 측정한 결과 $\mathrm{ZrN}$ 을 코팅한 경우가 코팅하지 않은 경우에 비하여 높은 표면 경도를 나타냈다. 따라서 시편에 $\mathrm{ZrN}$ 이 코팅된 경우에는 전류밀도가 감소하고 부 식전위가 증가하였으며 코팅 두께가 커질수록 부식특성 이 증가되었다.

3. 동전위시험결과 내공식성은 고주파주조법으로 제조 된 시편에서 $\mathrm{ZrN}$ 을 코팅한 경우가 가장 높게 나타났고 원 심주조법에서 낮게 나타났다.

4. 시편의 $\left|\mathrm{Emax}_{\max }-\mathrm{E}_{\text {rep }}\right|$ 값은 코팅하지 않는 경우가 $100 \mathrm{mV}$ 에 가깝고 $\mathrm{ZrN}$ 코팅된 경우가 내공식성이 우수한 
것으로 나타났다.

\section{REFERENCES}

Santhanam AT. Effects of TiN and ZrN Coating on Surface Characteristics, US Patent, 5, 257367, 1993.

Ramalho A, Viera MT, Miranda AS. Effects of TiN and ZrN Coating on Surface Characteristics of Orthodontic Wire. Edited by Mihaly Kosma, 3, 309, 1993.

Breme E, Einsenbarth H, Hilerbrand. Biomimetic Implant coating, Biomol Eng, 24, 27-32, 2007.

Brunette D, Tengvall MP, Textor M, Thomsen P. Production of Microfabricated S urfaces and Their Effects on Cell Behavior. Titanium in medicine, 1, 343-373, 2001.

Erturk E, Heuvel HJ. Adhesion and structure of TiN arc coatings. Thin Solid Films, 153, 135147, 1989.

Choe HC. Interface activation and surface characteristics of Ti/TiN/HA coated sintered stainless steels. Surf Coat Tech, 112, 299309, 1999.

Earnshaw R. Microstruct Lire and Physical Properties of Alloys for Partial Denture Castings. J Brit Dent, 67, 101, 1956.

Craig R, brien OWJ, power JM. Effect of Polishing Systems on the Surface Roughness of Microhybrid Composites. Restorative Dental materials, 2, 201, 1979.

Civilian S, Hugut EF, Errhard WL, Vaccaro GJ. Multiple Arteriosclerotic Arterial Aneurysms. J pros Dent, 28, 77, 1972. 